DOI: https://doi.org/10.46630/phm.12.2020.41

Бранко М. Ракић ${ }^{1}$

Прегледни рад

Универзитет у Београду

УДК 811.133.1’342.2

Филолошки факултет

Примљен: 1. 12. 2019.

Катедра за француски језик и књижевност

\title{
СТРАТЕГИЈЕ У САВРЕМЕНОЈ ФОНЕТСКОЈ КОРЕКЦИЈИ ФРАНЦУСКОГ ЈЕЗИКА: МОГУЋНОСТИ ПРИМЕНЕ У РАДУ СА СРБОФОНИМ СТУДЕНТИМА
}

У овом раду говорићемо о данас доминантним поступцима и стратегијама које се користе у фонетској корекцији француског као страног језика. Треба истаћи да су ови приступи и стратегије засновани на одређеним универзалним дидактичким приступима (попут еклектичког) и принципима који се и примењују у настави било којег страног језика данас. Најпре ћемо се осврнути на разлоге због којих је развијање фонолошке компетенције француског језика у потпуности, а сасвим неоправдано, занемаривано од седамдесетих па све до средине деведесетих година 20. века. Затим ћемо изнети синтезу ставова и корективних приступа најзначајијих француских дидактичара с краја 20. и почетка 21. века који су се борили и изборили за потпуну рехабилитацију фонетске корекције, како артикулаторне тако и прозодијске (GEMBRETJER 1994; ŠAMPANJMIZAR, BURDAŽ 1998; LEON 2003; LORE 2007). Наведени аутори констатовали су да на прелазу из 20. у 21. век, у дидактици страних језика уопште, па тако и у дидактици фонолошке компетенције влада начело еклектизма, то јест комбиновања доказано делотворних корективних фонетских стратегија и приступа преузетих из различитих дидактичких метода (директна метода, аудио-орална метода, структурално-глобална аудио-визуелна метода - СГАВ, комуникативни приступ). Ове закључке илустроваћемо примерима вежбања из савремених уџбеника за учење француског језика, елаборираних сходно поменутом начелу еклектизма (Forum 1, Champion 1, Phonétique progressive du français avec 600 exercices, Exercices systématiques de prononciation française, Enseigner la prononciation $d u$ français). Поред тога, настојаћемо да, уз помоћ наведених вежбања, укажемо на предности и евентуалне мане оваквих корективних стратегија у раду са србофоним студентима. Примери ових вежбања могли би, осим тога, да послуже као смернице за развијање корективних стратегија које би комбиновале различите типове вежбања, а према реалним корективним потребама које се јављају код групе, дела

1joliepuce11@yahoo.fr 
групе или појединаца који имају потешкоћа у овладавању изговорном или интонативном компетенцијом француског језика.

Кључне речи: еклектички приступ, артикулациона корекција, прозодијска корекција, вежбе перципирања, вежбе продукције

\section{Увод}

У овом раду, настојаћемо да дескриптивним приступом изнесемо синтезу најважнијих принципа и стратегија рада у процесу фонетске корекције француског језика које су елаборирали најзначајнији француски дидактичари с краја 20. и почетка 21. века (GEMBRETJER 1994; ŠAMPANJ-MIZAR, BURDAŽ 1998; LEON 2003; LORE 2007). Карактеристике ових стратегија илустроваћемо примерима из корпуса који чине два уџбеника за француски језик (Forum 1, Champion 1) и три специјализована приручника за увежбавање изговора француског језика (Phonétique progressive du français avec 600 exercices, Exercices systématiques de prononciation française, Enseigner la prononciation $d u$ français) у којима се јасно препознају стратегије наведених аутора. Циљ нам је, затим, да укажемо на предности и недостатке које ове стратегије могу да имају током примене у раду са србофоним студентима француског језика и на могуће смернице развоја засебних корективних стратегија које би наставник прилагођавао реалним корективним потребама појединца или групе.

Корективне фонетске стратегије поменутих дидактичара настале су као реакција на комуникативни приступ који се у дидактици страних језика развио седамдесетих и осамдесетих година 20. века. Наиме, према теоријским основама на којима је комуникативни приступ изграђен, језик је комуникацијско средство па у овом приступу у центру пажње више није учење садржаја, него ученик и његова комуникација. Услед тога, у наведеном периоду дошло је до потпуног занемаривања рада на фонетској корекцији и развијању изговорне и прозодијске компетенције страног језика.

То занемаривање фонетске компетенције проистекло је из примата комуникацијског чина у којем је, како запажају Галаци-Маташи и Педоја-Гембретјер (Galazzi-Matasci, Pedoya-Guimbretière) (1983: 40): „[...] le critère de la performance optimale (identité avec le système-cible) a été remplacé par le critère d'acceptabilité maximale des performances pourvu qu'elles n'entravent pas la communication." 2 . На то занемаривање утицао

${ }^{2}$, „[...]критеријум оптималне перформансе (идентичности са системом страног језика који се учи) замењен критеријумом максималне прихватљьвости перформанси под 
је и статус ученика који је у центру самог процеса учења. Наиме, у првом плану је ученикова способност самосталног и њему својственог изражавања у аутентичним говорним ситуацијама, при чему уместо пуког понављања граматичких и синтаксичких форми најважнију улогу има лично ангажовање у комуникацијском чину.

Због таквих схватања, рад на развоју фонетске компетенције свео се на просто навикавање ученика на прозодијске одлике страног језика помоћу снимљеног материјала, а у оквиру рада на усменом разумевању, будући да је у центру пажње разумевање, а не компетенција продукције.

Поред ових фактора, елиминисању фонетске корекције из процеса учења страних језика допринели су и одређени ставови који су се, касније, показали потпуно нетачним. Шампањ-Мизар и Бурдаж (ChampagneMuzar, Bourdages) (1998: 17), као главне кривце за маргинализацију фонетике, означавају следећа три става који су били веома раширени и дубоко укорењени у првим фазама развоја комуникативног приступа:

„1) l'exposition à la langue cible comme condition suffisante pour assurer le développement des habitudes articulatoires et prosodiques;

2) l'incapacité après la puberté d'acquérir une maîtrise des habitudes articulatoires et prosodiques de la langue cible ou l'hypothèse des contraintes biologiques ;

3) l'absence de répercussion d'un accent étranger sur la communication. “"

Галаци-Маташи и Педоја-Гембретјер примећују да се у раном периоду настанка комуникативног приступа сматра да систематски рад на развоју фонетске компетенције није потребан: ,[...] tout se passe comme si le problème essentiel était de mettre en contact les apprenants avec l'authenticité de la langue orale, et donc de les y habituer, la maîtrise du système phonologique pouvant s'acquérir tout naturellement par simple imprégnation [...]"“4. (GALACI-MATAŠI, PEDOJA-GEMBRETJER 1983: 39).

C друге стране, бројни су аутори који оспоравају такво виђење ствари, истичући да изговорне и прозодијске карактеристике страног језика није могуће савладати без систематског фонетског вежбања.

Да би показали нетачност тврдњи да се фонетска вежбања не морају инкорпорирати у процес учења страног језика, Шампањ-Мизар и условом да оне не отежавају комуникацију.“ (прев. аут.).

${ }^{3}$, „1) излагање страном језику довољан је предуслов за развијање изговорних и прозодијских навика;

2) после пубертета немогуће је оптимално овладати изговорним и прозодијским навикама (хипотеза о биолошкој принуди);

3) страни акценат не утиче на одвијање комуникацијског чина. “ (прев. аут.).

4, ,[...]све се одвија као да је најважније ученике изложити аутентичном усменом језику, и на њега их навићи, будући да се фонолошким системом може сасвим природно овладати најобичнијим излагањем страном језику[...]“. 
Бурдаж спровели су истраживање о улози рада на стицању фонетске компетенције у процесу учења страног језика, и то током периода од три месеца (ك̌SAMPANJ-MIZAR, BURDAŽ 1998: 19).

Ово истраживање изведено је са две групе одраслих особа на почетном нивоу учења француског језика. Прва, или експериментална група, је, током дванаест часова, систематски увежбавала изговорне и прозодијске карактеристике француског језика док је друга, контролна група, учила француски према методи у којој је рад на фонетској корекцији потпуно занемарен.

На основу добијених резултата, утврђено је да су полазници из експерименталне групе веома напредовали у дискриминацији и репродукцији сегменталних елемената (гласова) и супрасегменталних (прозодијских) карактеристика француског језика, док, код полазника из контролне групе, то није био случај, па је изведен закључак да ученици неће много напредовати у стицању изговорних компетенција ако их само излажемо страном језику, то јест, ако су само пасивни слушаоци датог страног језика. (ک̌AMPANJ-MIZAR, BURDAŽ 1998: 20).

Ова и слична истраживања довела су, осамдесетих и деведесетих година 20. века до ревалоризовања систематичног рада на стицању фонетске компетенције, и то највише на савладавању прозодије страног језика којој су многи аутори придавали изузетно велики значај сматрајући је кључном за разумевање поруке у комуникацијском чину и за овладавање фонолошким системом страног језика.

\section{1. Фонетска корекција француског језика на крају 20. и почетку 21. века}

Током деведесетих година 20. и на почетку 21. века, фонетска корекција поново добија на важности, па јој је у свим уџбеницима за учење француског језика у овом раздобљу додељена изузетно значајна улога.

Многи аутори међу којима и Елизабет Гембретјер (Élisabeth Guimbretière) залажу се за следећи принцип у фонетској корекцији: „[...] prendre et [...] ne garder que ce qui paraît avoir fait ses preuves, servir en quelque sorte l'outil pédagogique [...]“"5. (GEMBRETJER 1994: 52).

Кристијан Пирен (Christian Puren) овакав принцип рада у дидактици француског као страног језика назива еклектичким (PIREN 1994: 7) и под њим подразумева комбиновање доказано ефикасних техника, стратегија рада и поступака наслеђених из различитих метода за учење страних језика које су развијене до данас (директна, аудио-орална, структурал-

${ }^{5},[. .$.$] узети и задржати само оно што се доказало као добро и што може да послужи$ педагошкој сврси[...]““. 
но-глобална аудио-визуелна метода - СГАВ, комуникативни приступ).

Уџбеници за учење страних језика уопште, а самим тим и приступи фонетској корекцији унутар њих, као и специјализовани приручници намењени учењу изговора и савладавању прозодијских особености страног језика данас почивају на наведеном принципу еклектизма.

Еклектички приступ најбоље илуструју типологије метода и техника фонетске корекције које крајем 20. и почетком 21. века предлажу многи значајни аутори: Лебел (Lebel) (1990), Селс-Мурсија (Celce-Murcia) (1996), Шампањ-Мизар и Бурдаж (1998) и Лоре (Lauret) (2007).

Заједничке карактеристике свих наведених типологија сажели бисмо констатацијом да почивају на принципу:

1) да се правилно перципирање увек ставља испред продукције;

2) да ученика што чешће треба излагати усменом који мора претходити писменом језику;

3) да сваки тип активности на пољу фонетске корекције увек треба прилагођавати циљу учења језика;

4) да се у обзир узима чињеница да је неопходан избалансиран приступ увежбавању сегменталних феномена (гласова) и супрасегменталних карактеристика (акцента, ритма, интонације);

5) да се, у погледу прогресије у процесу наставе, треба придржавати принципа: ићи од једноставнијег ка сложеном. Фонетску корекцију треба такође спроводити на примерима састављеним најпре од једноставних, а затим од све сложенијих слоговних структура. Примери се, у почетку налазе у олакшавајућем контексту који затим прераста у много сложенији;

6) да, у процесу фонетске корекције, треба прибегавати раду у традиционалним фонетским лабораторијама, али и савременим мултимедијалним средствима.

Сумирајући ове принципе, може се закључити да настава фонетике у оквиру наставе страних језика има за циљ, најпре, да ученик буде довољно разумљив тако да може коректно да пренесе поруку саговорнику, изворном говорнику страног језика. Крајњи циљ није стицање оптималне фонетске компетенције (осим у случају да ученик за то покаже интересовање) него проток информација. Настава фонетике, затим, треба да оспособи ученика/студента да самостално развија фонетске навике и да приступа ауто-корекцији, што се, према техници за коју се залажу Шампањ-Мизар и Бурдаж (1998: 38-40) може постићи сажетим објашњењима о томе како се одређени гласови артикулишу. Оваква објашњења могу се илустровати графиконима на којима су приказани делови говорног апарата и положаји у којима се током творбе одређених гласова налазе делови 
говорног апарата који их продукују. На графиконима се може видети кретање језика, затим да ли су усне заобљене или развучене, да ли је степен апертуре уста мањи или већи, итд. Студента би, затим, требало упутити и у међународни фонетски алфабет како би са̂м могао да потражи у речницима ознаке за изговор речи.

Да би студент могао са̂м да исправи сопствени изговор или интонацију, неопходно је да изузетно добро овлада способношћу дискриминације, без које нема ефикасне ауто-корекције, јер ако се грешка не увиди, не може се ни исправити.

\section{2. Анализа корпуса}

У анализи корпуса који чине два уџбеника за француски језик (Forum 1, Champion 1) и три специјализована приручника за увежбавање изговора француског језика (Phonétique progressive du français avec 600 exercices, Exercices systématiques de prononciation française, Enseigner la prononciation du français), размотрићемо следећа питања:

1) да ли су фонетске корективне вежбе како на сегменталном (корекција изговора гласова) тако и на супрасегменталном нивоу (акценат, ритам и интонација) у овим уџбеницима елабориране сходно принципима корективних стратегија француских дидактичара наведених у уводном делу нашег рада;

2) које су предности или евентуални недостаци наведених типова вежбања, а које смо увидели у свом досадашњем искуству у раду са србофоним студентима;

3) колико су наведени типови вежбања примењиви у универзитетској наставној пракси код нас.

Наведени француски дидактичари с правом сматрају да рад на фонетској корекцији мора да отпочне вежбама правилног перципирања, а пре било каквог вежбања продукције, то јест изговора.

Наше досадашње искуство у раду са србофоним студентима уверило нас је у потпуну оправданост наведеног принципа рада: од правилног перципирања ка правилној продукцији. Другим речима, ако студент „не чује“" да је погрешио, то јест ако није свестан своје грешке, ту грешку неће моћи ни да исправи.

Пример из наше досадашње праксе који бисмо навели је изговор француског самогласника [y] који за значајан број наших студената представља и један од највећих проблема у овладавању француским гласовним системом. Будући да овај самогласник не постоји у фонолош- 
ком систему српског језика, поједини студенти погрешно га перципирају и у почетку погрешно и продукују као [i], односно [u]. Када им се скрене пажња да се, на пример, реч la voiture изговора [lavwaty:R], a не [lavwatu:R], већина њих одговори да је тако и рекла, то јест, поново погрешно изговори и каже [lavwatu:R] jep је глас погрешно и перицпирала.

Ово илуструје колико је битна почетна фаза у фонетској корекцији која мора отпочети сензибилизацијом, навикавањем студента на нове фонолошке реалности, на гласове који не постоје у његовом матерњем језику, а како би те гласове могао правилно да перципира и затим да их и изговара.

Став горе поменутих француских дидактичара да се правилно перципирање увек ставља испред продукције можемо препознати у вежбањима аудитивне сензибилизације, како их називају Шампањ-Мизар и Бурдаж (1998: 54-55).

Ове вежбе имају за циљ да помогну студентима да правилно перципирају ритам, интонацију и гласове страног језика. Тако, на пример, студентима треба скренути пажњу на прозодијске карактеристике француског језика путем дијалога или низа неповезаних реченица у којима наведене прозодијске карактеристике јасно долазе до изражаја.

За реализоавање оваквих вежби није неопходно превише времена и могу се реализовати помоћу техничких средстава за репродукцију звучних записа која су свима доступна (ЦД плејер, компјутер, а у данашње време чак и мобилни телефон и таблет). Поред тога, графичко обележавање интонативних карактеристика врло јасно указује на интонативне карактеристике афирмативних односно интерогативних исказа, па можемо констатовати да наши студенти овакве типове вежбања веома брзо и успешно савладају.

1. L'intonation assertive est caractérisée par une inflexion descendante finale : C'est difficile.? C'est difficile de s'exprimer en français.

2.1 L'intonation interrogative est toujours caractérisée par une inflexion montante finale s'il n'y a pas de structure syntaxique interrogative :

C'est difficile? $f$

Слика 1. Пример прозодијских упутстава из методе Phonétique progressive du français avec 600 exercices (ŠSARLIJAK, MOTRON 1998: 20).

Други тип вежбања према Шампањ-Мизар и Бурдаж (1998: 54-55) су вежбе сензибилизације на визуелно представљање артикулације гласова, па, у оквиру ових вежби, препоручују коришћење илустрација са приказима говорног апарата, положајем одређених органа у говорном апарату, итд. 
Иако се слажемо са потребом упућивања студената у начин артикулације појединих гласова и путем ових графикона и путем објашњења како се они артикулишу, овде бисмо желели да укажемо на чињеницу да оваква упутства могу бити контрапродуктивна уколико их професор изнесе пре већег броја претходно урађених вежби перцепције и дискриминације гласова који представљају проблем студентима. За пример ћемо поново узети француски самогласник [y] чија је артикулација приказана на слици 2.

Наиме, после објашњења да су приликом артикулације француског самогласника [у] усне заобљене као приликом изговора самогласника [u], а да језик иде напред као приликом изговора гласа [i], многи студенти доживе потпуну блокаду обраћајући искључиво пажњу на то како да наместе уста и језик.

Оваква ситуација може да их демотивише и потпуно блокира у процесу овладавања коректним изговором па још једном желимо да истакнемо да би овакав вид објашњења у наставни процес требало увести тек после дуже припреме у виду већег броја вежби перцепције и дискриминације гласова [y], [u] и [i].

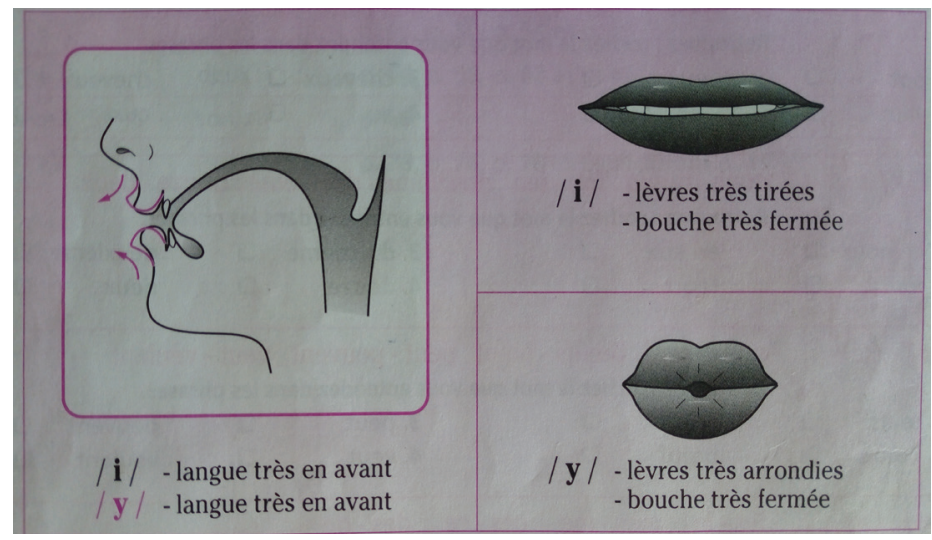

Слика 2. Пример артикулаиијских упутстава из методе Phonétique progressive du français avec 600 exercices (ŠARLIJAK, MOTRON 1998: 46).

Пример визуелне сензибилизације на ритмичке и интонативне обрасце која може да помогне правилном перципирању интонације и ритма приказан је на слици 3. После истовременог слушања реченице и гледања у интонативне схеме на којима је стрелицама указано на кретање интонације, студенти јасно увиде и усвоје карактеристике кретања интонације француских изјавних, односно упитних реченица. 


\section{GXERCICE 1}

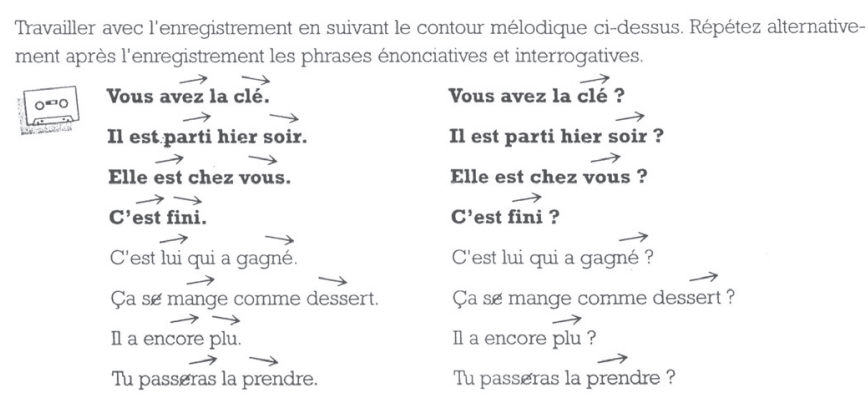

Слика 3. Схематско приказивање интонације према Моник Леон (2003: 109)

Други тип вежбања које оспособљавају студенте да правилно перципирају гласове и прозодијске феномене француског језика, према Шампањ-Мизар и Бурдаж (1998: 57-63) представља аудитивна дискриминација током које студент треба да пореди и разликује гласове и прозодијске феномене француског језика.

Током ове фазе, на сегменталном нивоу, може се прибећи вежбањима поређења-избора у којима студент треба да каже да ли су две, три или више речи или исказа исти или различити, затим вежбањима поређења исказа на матерњем и страном језику како би студенти увидели које фонетске разлике постоје између два фонолошка система.

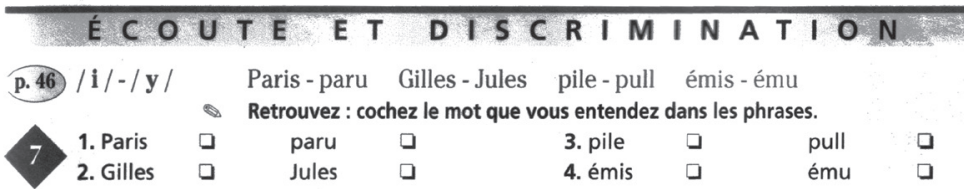

Слика 4. Примери вежбања поређења-избора у приручнику Phonétiquе progressive du français avec 600 exercices (ŠARLIJAK, MOTRON 1998: 45).

\section{Phonétique}

Les sons / i/ comme dans tarif, /y/ comme dans sûr et /u/comme dans séjour.

1 (1) Écoutez et mettez une croix quand vous entendez le même son.

\begin{tabular}{|l|l|l|l|l|l|l|l|l|l|}
\cline { 2 - 8 } \multicolumn{1}{c|}{} & a & b & c & d & e & f & g & h & i \\
\hline DIFFÉRENT & & & & & & & & & \\
\hline IDENTIQUE & & & & & & & & & \\
\hline
\end{tabular}

21 Écoutez et mettez une croix quand vous entendez le son /u/ comme dans séjour.

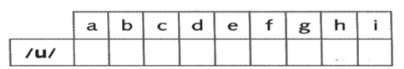

Слика 5. Примери вежбања поређења-избора у унбенику Chaтpion 1 (MONRIGOAREN, SIREŽOL 2001: 54). 
Затим су ту задаци чији је циљ идентификовање одређеног гласа. Студенти треба да распознају и означе у табели колико пута чују одређени глас у датом исказу, или у којим речима га има или нема, или у којем се слогу јавља. Код њих се оваквим типом задатака развија перцепција одређених гласова.

\section{Phonétique}

8 a. Combien de fois entendez-vous le son [s] comme dans citron ou tasse.

a. fois. b. ............ fois.

b. Combien de fois entendez-vous le son [z] comme dans maison.

c. ........... fois.

d. ............ fois.

Слика 6. Примери вежбања идентификачије у уцбенику Champion 1 (MONRI-GOAREN 2001: 34).

Један од принципа на којима почивају корективне стратегије француских дидактичара о којима смо говорили у уводном делу рада је и да се у раду на фонетској корекцији, у обзир узме чињеница да је неопходан избалансиран приступ увежбавању сегменталних феномена (гласова) и супрасегменталних карактеристика (акцента, ритма, интонације) страног језика. У уџбенику Champion 1, овај принцип је испоштован што можемо да видимо на слици 7. на којој је приказано вежбање које за циљ има акценатску и ритмичку организацију француског језика.

Наиме, у овом вежбању, путем равних црта које указују на дужење вокала којим се реализује француски акценат сугерисано је на којим се слоговима налази акценат, где се налазе границе између ритмичких група, и самим тим од колико се ритмичких група састоји дати исказ.

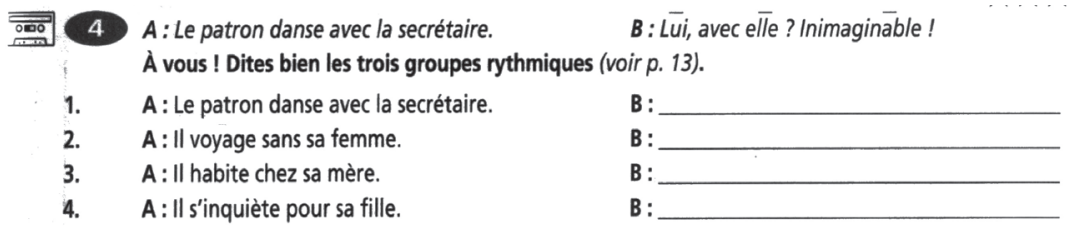

Слика 7. Рад на ритмичким групама у методи Phonétique progressive du français avec 600 exercices (ŠARLIJAK, MOTRON 1998: 29).

На супрасегменталном нивоу, као примере за задатке идентификације можемо навести и пример на слици 8. Пошто најпре чују одређени исказ, студенти треба да одреде која ритмичка или интонативна схема од понуђених одговара датом исказу. 
Они могу и да добију задатак да саслушају два исказа и да затим кажу да ли се искази разликују по ритму или по интонацији, као и задатак да одреде од колико се ритмичких група састоји дати исказ, или да на основу интонације одреде о којем се типу исказа ради.

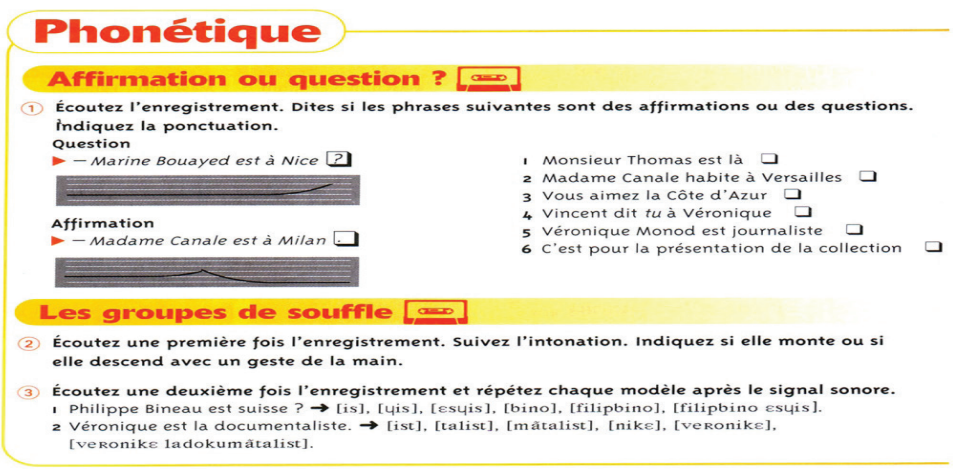

Слика 8. Примери вежбања прозодијске идентификације у уцбенику Foruт 1 (BELON 2000: 32).

Ове две фазе, дакле фазу сензибилизације и фазу дискриминације према Шампањ-Мизар и Бурдаж (1998: 54-63), Лоре у својој типологији (LORE 2007: 140) назива задацима перциинирањ a (les tâches de perception) који се састоје од загревања за перципирање, то јест, од опуштања, правилног и мирног дисања, затим од давања јасних и детаљних упутстава ученику шта треба да уради, на шта треба да обрати највећу пажњу приликом изговора, затим од фазе питања и одговарања, и на крају од фазе свођења биланса и дискусије о ономе што је ученик перципирао, а током које студент под будним оком наставника може да дође до одређених артикулаторних, акустичких, сегменталних и супрасегменталних закључака.

Такво информисање и давање објашњења у вези са проблемом који се обрађује, наставник може да илуструје и ритмичким и интонативним схемама, затим објашњењима у вези са артикулаторним карактеристикама која могу бити праћена сликама говорног апарата током артикулације одређеног гласа, или међународном фонетском транскрипцијом. Такав вид активности Лоре назива аналитичким активностима (LORE 2007: 149), које раздваја од вежбања. Вежбања служе за увежбавање способности перципирања и репродуковања гласова и прозодијских карактеристика страног језика, и то понављањем модела у виду ограниченог низа речи или исказа, што наставник затим треба да подвргне евалуацији и поређењу са моделом. С друге стране, активности се, према Лореу, не заснивају на понављању задатог модела, и на евалуацији учениковог учинка, него ученика наводе на размишљање и буде у њему креативност 
(LORE 2007: 138). Ова његова подела на вежбања и активности заправо је подела на вежбања (exercices) и задатке (tâches) која је у средишту акционог приступа за који се данас залаже већина дидактичара.

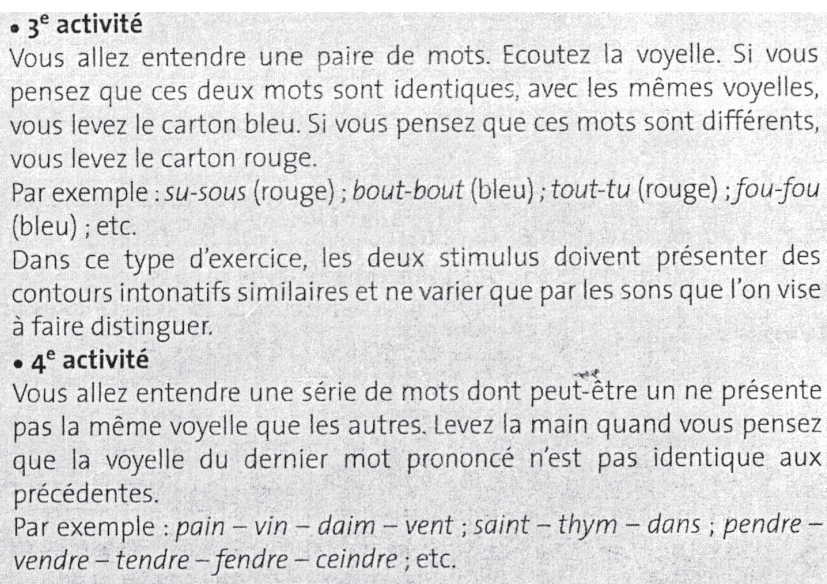

Слика 9. Примери вежби дискриминащчије (LORE 2007: 141).

Током ове фазе перципирања, и Лоре препоручује рад на вежбама дискриминације одређених фонетских феномена (слика 9). Он скреће, притом, пажњу на чињеницу да се приликом дискриминације парова речи, дате речи не смеју разликовати по интонацији, него само по гласу који ученици треба да савладају, као и на чињеницу да рад на дискриминацији мора да траје све док ученици не постигну 80-90\% тачних одговора и да, тек онда, може да се пређе на вежбе идентификације. (LORE 2007: 141) (слика 10).

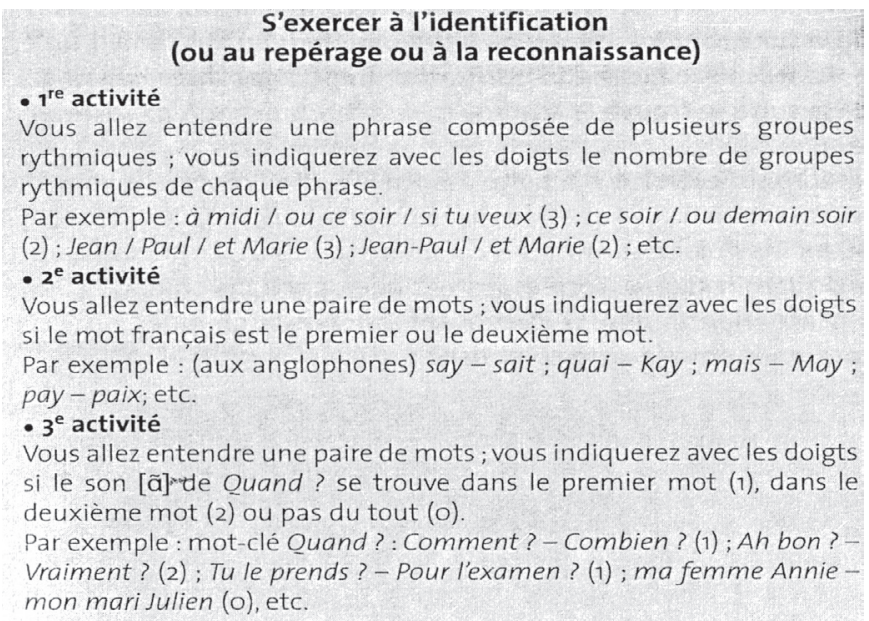

Слика 10. Примери вежби идентификаџије (LORE 2007: 142). 
Главни циљ обе ове врсте задатака везаних за перципирање јесте да студент препозна и усвоји одређени глас или ритмички и интонативни образац у опозицији са другим гласовима, то јест ритмичким и интонативним обрасцима. Као и у случају претходних уџбеника из нашег корпуса, и код Лореа је присутан избалансиран приступ увежбавању сегменталних феномена (гласова) и супрасегменталних карактеристика (акцента, ритма, интонације).

Када је реч о ритмичким карактеристикама француског језика, дужење последњег слога у ритмичкој групи треба да прати покрет који дочарава дужину, што наставник може да сугерише тако што ће испружити руку или повлачити оловку испред себе.

О овој фази, после Шампањ-Мизар и Бурдаж, говори и Лоре (2007: 146-147), и у оквиру ње, о вежбањима у којима поред гласа, треба да учествује и тело, а која се, такође, спроводе кроз етапе загревања, давања упутстава, кроз етапу стимулуса/одговора, и на крају кроз свођење биланса и дискусије о репродукованом фонолошком корпусу.

Тако, да би се овладало карактеристикама француског ритма, Лоре предлаже комбинацију физичке и вокалне активности: ученик по столу, на простору од тридесет центиметара, гура оловку или парче папира и то током изговора наглашеног слога чиме се пажња скреће на дужење вокала у наглашеном слогу.

У случају да се одређена реченица завршава затвореним [е], студенти би, према Лореу (2007: 147), требало да савију руке и рашире лактове што даље од себе, што упућује на артикулаторну особину овог вокала, то јест на развученост усана, а у случају да се исказ завршава затвореним [ø], студент треба да скупи лактове и испред себе их стегне један уз други, чиме се сугерише да у артикулацији овог лабијалног гласа, усне играју велику улогу.

Лоре, поред тога, препоручује и употребу огледала, и то тако да студент испред огледала вежба са моделом, то јест са наставником, јер ће тако моћи истовремено да види и како сам артикулише одређени глас и како га артикулише модел.

Имајући у виду да је број часова фонетике у нашој универзитетској пракси веома ограничен, овде бисмо могли да приметимо да је начин рада који препоручује Лоре веома делотворан, али и временски презахтеван па га је веома тешко у целости спровести у дело у раду са студентима. У таквим ситуацијама, наставници би требало да прибегну ономе што Пирен (1994: 10-12) назива ,адаптацијским еклектизмом“ (l'éclectisme d'adaptation). Дакле, у овом конкретном случају, требало би извући оно најбоље из Лореовог приступа и у пракси искомбиновати са најбољим тековинама свих дидактичких метода (директна, аудио-орална, 
СГАВ, комуникативни приступ), њиховим најделотворнијим техникама и фонетским вежбањима које притом не захтевају превише времена и те технике и вежбања прилагодити ситуацији на терену, то јест потребама наставног процеса и циљу учења језика.

После уводне фазе која је посвећена усменом коду, аутори свих уџбеника и приручника из нашег корпуса, а сходно корективним стратегијама француских дидактичара које смо навели у првом делу овог рада, препоручују рад на повезивању усменог и писменог кода, гласа и графије, али и повезивању мелодијских феномена са одређеном графичком схемом.

Овај рад може се састојати од неколико типова вежби, и то од вежби вођеног поређења током којих студент треба да, између неколико понуђених написаних верзија, изабере ону која одговара ономе што је чуо, затим од вежби идентификовања у којој се реченици или реченицама налази одређена кључна реч коју је најпре чуо, а за њом и три исказа.

Следећи тип вежбања у оквиру ове фазе рада била би транскрипција задата у виду диктата у којима студент попуњава празнине на којима треба да се нађе графија или графије које одговарају гласу који се обрађује, или вежбе у којима треба да подвуче графију или графије које одговарају одређеном гласу. Примере како би изгледала та вежбања, можемо да видимо на следећој слици.

\section{Graphie}

12 Écoutez et complétez avec e, é, ez, è, es, est ou ai (aî).

1. J'...... 19 ans. Je suis ......tudiante. Je suis gr.......cque.

2. C'est une Italienne. Elle ...... m......decin et elle habite ici.

3. Vous envoy...... un ch......que banc...... re ou vous pay...... par carte bleue?

4. Je voudr......s un num...... ro de t............phone, s'il vous pl......t!

5. Tu ...... franç...... se? Non, je suis am...... ric.......ne.

Слика 11. Пример вежби за овладавање писаним кодом (MONRI-GOAREN 2001: 10).

Овакав вид вежбања, Лоре (2007: 148) назива les tâches nécessitant un support écrit (задацима који захтевају употребу писаног језика) и у њих убраја цртеже и схеме, као и упитнике које студент треба да попуни, и вежбе у којима треба или да подвуче одређени глас или слог у којем са дати глас налази. Он, такође, може са̂м да попуни празнине одређеном графијом. Примену оваквих вежби Лоре препоручује тек пошто студенти почну правилно да перципирају, а самим тим и да репродукују фонеме које им представљају проблем. 
Бранко М. Ракић

\section{Identifier à partir de l'écrit}

- Dans des exercices d'identification utilisant des paires minimales :

Écoutez et soulignez ce que vous avez entendu.

Par exemple : au dessus / au dessous ; C'est vu ? I C'est vous? ; Tu l'as

lu? I Tu la loues?

- Dans des exercices d'identification utilisant un texte :

Écoutez et soulignez les syllabes qui contiennent le son entendu.

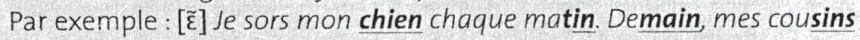
viennent à Reims avec leur chienne et leurs cing enfants.

- Dans les textes à trous :

Écoutez et remplissez les espaces par l'orthographe qui convient

$(\langle o u\rangle,\langle u\rangle)$

Par exemple : C'est $t-t$ ? T-es s-r? - s-per! Merci beauc-p. Alors $t$ - l'as

1-? - Jait-t I.

Слика 12. Пример „задатака који захтевају употребу писаног језика“ (LORE 2007: 149).

Поред наведених вежби, у оквиру ове фазе, Лоре препоручује још два друга типа вежбања: писмене продукције (диктати и диктати са логатомима) и усмене продукције (гласно читање текста).

После свих наведених типова вежбања које студенте треба да оспособе да правилно перципирају гласовне и акценатско-интонативне карактеристике француског језика, треба прећи на фазу вођене продукције. Ова дидактичка техника подразумева, према Шампањ-Мизар и Бурдаж (1998: 68-71), вежбе које за циљ имају развијање способности перципирања и продукције како на пољу изговора, тако и на пољу прозодије. Она се састоји из неколико физичких активности: вежбе правилног дисања, загревања мишића говорног апарата постепеним отварањем и затварањем уста, масирањем образа, зевањем, осмехивањем, и свим оним што може да покрене мишиће лица.

Затим следе вежбе индивидуалног и колективног понављања и, на крају, вежбе трансформације током којих студент треба да измени исказ или у смислу гласова који се у њему јављају, или у прозодијском смислу и да затим саслуша очекивани одговор и упореди га са својом продукцијом.

Овде бисмо поново могли да изнесемо напомену о малом броју часова фонетике у нашој универзитетској пракси и констатацију да би наведене типове вежби било веома тешко реализовати у целости. Управо због тога, кључну улогу у реализацији наставног процеса фонетске корекције морао би да има сам наставник који од свих понуђених техника и типова вежбања треба да изабере најподесније, то јест оне које су најприлагођеније конкретним изговорним проблемима студената, а чија реализација притом не захтева превише времена.

Последњу фазу у корективном раду би представљала спонтана продукција током које студент стечена фонетска знања треба да примени у природном или аутентичном контексту. 
Лоре овакав тип вежбања назива les tâches de production (задащии продукųuje) (LORE 2007: 143). Ови задаци представљају најважнији део фонетских вежбања и, као и у случају задатака перциичрања, код Лореа се састоје од фазе: 1) загревања, слушања упутстава, постављања питања и добијања одговора и 2) свођења биланса и дискусије о ономе што је ученик репродуковао.

Лоре (2007: 144) истиче да је у оквиру задатака продукиије, циљ свих вежбања да студенти коректно репродукују гласове и интонативне и ритмичке обрасце страног језика, не ослањајући се притом на писани језик, него само на непосредно памћење. Стога искази које студент треба да понови морају да буду кратки.

Као веома занимљива вежбања, с прозодијске тачке гледишта, Лоре (2007: 144) предлаже да студенти, како би увидели ритмичке и интонативне карактеристике француског језика, најпре подражавају француски акценат тако што ће матерњи језик говорити са француским акцентом. Други тип вежбања би се састојао од тога да студенти најпре репродукују француски исказ, да га затим преведу на матерњи језик, да га тако преведеног изговоре са израженим француским акцентом, и да, на крају, исту реченицу изговоре на француском.

Најчешћи тип вежбања током ове фазе задатака продукиије су вежбе подражавања, понављања и трансформације, у којима студент треба да саслуша и затим подражава одређени глас, на пример једнолични глас робота, затим глас који приповеда причу или глас којим се неко обраћа беби, затим да саслуша и понови одређене гласове, слогове, речи и реченице, варирајући притом темпо говора, начин говора, од шапутања до викања и затим од слушања и давања одговора прибегавањем интонативној, лексичкој или граматичкој трансформацији.

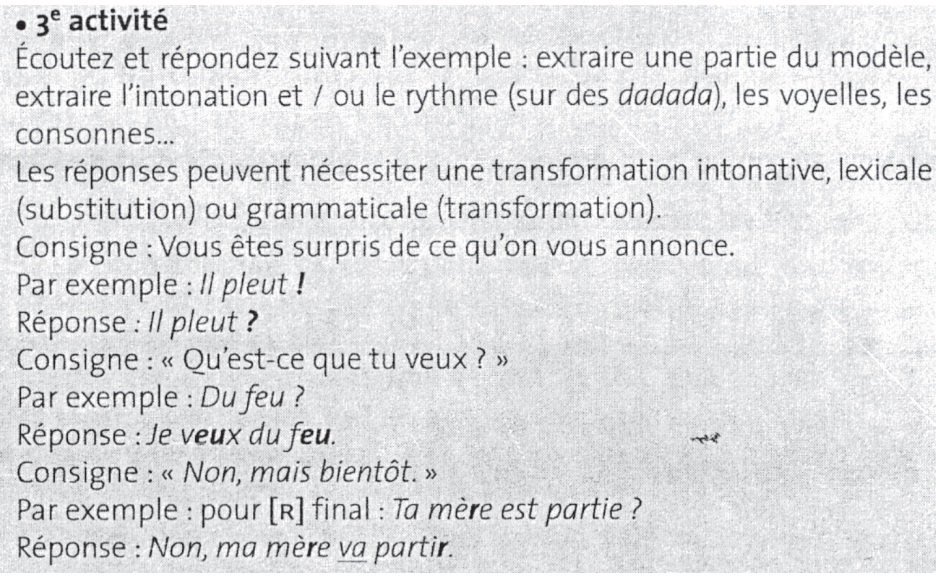

Слика 13. Вежбе слушања и одговарања путем интонативне, лексичке или граматичке трансформаиије (LORE 2007: 145). 
Најкомплекснији тип вежбања која се могу јавити у оквиру задатака продукuије су игре по улогама јер се искази у овим вежбањима најпре морају разумети, понављати неколико пута и запамтити да би студент затим могао да се фокусира на изговорне карактеристике и проблеме који се у датим исказима јављају.

\section{Jeu de rôles}

Arthur / Julie; A. salue J. et lui demande comment elle va ; J. lui demande des nouvelles de sa voiture ; A. commence à parler d'un truc qui ne marche plus; Mais zut! J. s'excuse et court car voilà le bus.

Слика 14. Пример вежбе „игра по улогама“ (LORE 2007: 146).

Када је реч о најчешће коришћеним техникама у фонетској корекцији, Шампањ-Мизар и Бурдаж (1998: 72-74) скрећу пажњу на чињеницу да постоје технике које помажу стицању рецептивних (правилно перципирање гласова и прозодијских карактеристика) и репродуктивних компетенција (правилна продукција гласова и прозодијских карактеристика).

За правилно перципирање гласова, ауторке препоручују истицање проблематичних гласова помоћу, на пример, фокализацијског акцента (accent de focalisation) који је познат и под називом акценат за инсистиpaње (accent d'insistance) ${ }^{6}$, који треба поставити на слог у којем се дати глас налази, или премештањем датог слога на друго место у оквиру исказа, као у примеру Tu le feras? (To ћеш урадитu?) што постаје Le feras-tu? (Хоћеш ли то урадити?).

Боље перципирање сегменталних елемената може се постићи и мењањем гласовног окружења у којем се проблематични глас налази, односно смештањем датог гласа у повољни гласовни контекст који олакшава његово перципирање и премештањем датог гласа на почетак [lis], у средину [delivR] или на крај сегмента [mil] (ك̌SAMPANJ-MIZAR, BURDAŽ 1998: 73).

\footnotetext{
${ }^{6}$ Фокализацијски акценат (RAKIĆ 2011) погађа иницијални део речи и омогућава истицање неког мањег сегмента у синтагми, а може се реализовати снажним глоталним ударом, дужењем првог сугласника у речи, наглим и значајним растом основне фреквенције $\left(\mathrm{F}_{0}\right)$ и повећањем интензитета.

Фокализацијски акиенат може бити афективног типа (accent affectif) и дидактичког или интелектуалног типа (accent didactique/intellectuel). Под фокализацијским акцентом афективног типа подразумевамо дужење првог сугласника у речи која има неку афективну вредност или која се изговара уз осуду: c'est fformidable или c'est éppouvantable. Под фокализаиијским акцентом дидактичког типа подразумевамо истицање првог слога у синтагми коју желимо да ставимо у први план, а користи се најчешће да би се означила супротност између нека два појма: Ce n'est pas un a "antérieur, c'est un a p"ostérieur, On ne dit pas l"a garçon, mais l"e garçon.
} 
Правилном перципирању гласова може, затим, да допринесе и коришћење фонетске транскрипције која гласове ставља изнад графије и скреће пажњу на одређене фонетске феномене попут везивања, пада немог [ə], као и на феномене на које утичу међусобни односи у које ступају елементи у гласовном низу.

За правилну продукцију, Шампањ-Мизар и Бурдаж (1998: 72-74) препоручују прибегавање артикулаторним схемама, аудио и видео документима, али и коришћењу огледала у којима студент треба да посматра артикулацију гласова, затим чулу додира захваљујући којем студент може да осети органе говорног апарата и њихову улогу у процесу артикулације, па тако може, уколико стави руку на гркљан, да осети вибрирање гласних жица током творбе звучних консонаната и одсуство тог вибрирања током артикулације безвучних консонаната.

На крају, за побољшавање усмене продукције, ауторке Шампањ-Мизар и Бурдаж (1998: 72-73) препоручују технику модификовања гласа: на пример, изговором француског предњег вокала [у] студент може да овлада ако прибегне такође предњем, али развученом вокалу [i] који треба да заобли.

Ако је у питању савладавање прозодијских карактеристика страног језика, ауторке Шампањ-Мизар и Бурдаж (1998: 74) запажају да студенти могу прибећи гестовима којима означавају ритмичке групе тако што руком ударају ритам или сугерисањем кретања мелодије у реченици покретима руке који указују на спуштање, односно подизање гласа. Ова техника обележена је и одговарајућим стрелицама на следећој слици.

\section{Phonétique}

\section{L'interrogation avec ou sans mot interrogatif $\Leftrightarrow$}

(1) Écoutez l'enregistrement et observez les courbes intonatives correspondantes. Faites un geste d'accompagnement.

1 Où est-ce que tu es?

2 Tu ne vas pas venir?

4. Pourquoi veux-tu qu'elle téléphone?

3 Elle a téléphoné?

5 Quand est-ce qu'on peut aller au chalet ?

6 on va etre combien?

(2) Écoutez et répétez les phrases.

(3) Lisez les phrases ci-dessus et relevez les phrases avec des mots interrogatifs. Dans ces phrases, est-ce que l'intonation monte ou descend?

Слика 15. Пример рада на прозодији реченице (BELON 2000: 88). 


\section{3. Закључак}

Имајући у виду принципе на којима су изграђене корективне стратегије највиђенијих дидактичара који се баве стицањем фонолошко-прозодијске компетенције француског као страног језика које смо представили у уводу и у првом делу рада и узимајући у обзир анализу корпуса, можемо да закључимо следеће:

1) савремени приступи у фонетској корекцији француског језика почивају на начелу еклектизма, то јест на коришћењу техника из свих досадашњих метода за учење страних језика (директна метода, аудио-орална метода, СГАВ, комуникативни приступ), оних техника које ученику/ студенту омогућавају да, на што ефикаснији начин, овлада прозодијским структурама и правилним изговором страног језика;

2) у раду на стицању изговорне и интонативне компетенције императив је да рад на правилном перципирању одређених проблематичних гласова и прозодијских карактеристика мора да претходи увежбавању правилне продукције наведених феномена; затим да употреба усменог језика мора да претходи прибегавању писаном коду и да је неопходан равномеран приступ увежбавању гласова и прозодијских карактеристика француског језика;

3) анализом предности и недостатака уџбеника и приручника из нашег корпуса, а имајући у виду недостатак времена посвећеног фонетској корекцији француског језика у нашој универзитетској пракси, изнели бисмо следећи закључак: најважнији задатак наставника је да сам елаборира посебне, „персонализоване“ корективне стратегије усмерене ка исправљању грешака које констатује током корективног процеса код студената, и то тако што ће комбиновати најподесније стратегије, технике и вежбања које предлажу француски дидактичари у својим еклектичким приступима.

\section{Цитирана литература}

BELON 2000: BAYLON, Christian. Forum 1. Paris : Hachette, 2000.

GALACI-MATAŠI, PEDOJA-GEMBRETJER 1983: GALAZZI-MATASCI, Enrica; Pedoya-Guimbretière, Élisabeth. „Et la pédagogie de la prononciation?". Le français dans le monde, 180, (1983): pp. 39-44.

GEMBRETJER 1994: GUIMBRETIÈRE, Élisabeth. Phonétique et enseignement de l'oral. Paris : Didier / Hatier, 1994.

LEON 2003: LÉON, Monique. Exercices systématiques de prononciation française. Paris : Hachette, 2003. 
LORE 2007: LAURET, Bertrand. Enseigner la prononciation du français: questions et outils. Paris : Hachette, 2007.

MONRI-GOAREN 2001: MONNERIE-GOARIN, Annie. et al. Champion 1. Cahier d'exercices. Paris : CLE international, 2001.

MONRI-GOAREN, SIREŽOL 2001: MONNERIE-GOARIN, Annie; Siréjols, Évelyne. Champion 2, Paris : CLE international, 2001.

PIREN 1994: Puren, Christian. La didactique des langues étrangères à la croisée des méthodes. Essai sur l'éclectisme. Saint-Cloud/Paris : Crédif/Didier, 1994.

RAKIĆ 2011: RAKIĆ, Branko. „Fokalizacijski akcenat u francuskom jeziku”. Anali Filološkog fakulteta, 23/II (2011): str. 207-228.

ŠAMPANJ-MIZAR， BURDAŽ 1998: CHAMPAGNE-MUZAR， Cécile; Bourdages, Johanne. Le point sur la phonétique. Paris : CLE international, 1998.

ŠARLIJAK, MOTRON 1998: CHARLIAC, Lucile; Motron, Annie-Claude. Phonétique progressive du français avec 600 exercices. Paris : CLE international, 1998.

Извори

LEBEL 1990: LEBEL, Jean-Guy. Traité de correction phonétique ponctuelle. Laval : Les Éditions de la faculté des lettres, 1990.

SELS-MURSIJA 1996: CELCE-MURCIA Marianne et al. Teaching pronunciation: a reference for teachers of english to speakers of other languages. Cambridge: Cambridge University Press, 1996.

Branko Rakić

\section{LES STRATÉGIES DANS LA CORRECTION PHONÉTIQUE DU FRANÇAIS AUJOURD'HUI : LES POSSIBILITÉS D'APPLICATION DANS LE TRAVAIL AVEC LES ÉTUDIANTS SERBOPHONES}

Dans cet article, nous abordons le sujet de la place que la correction phonétique occupe de nos jours dans l'enseignement du français langue étrangère (FLE). Cet enseignement est caracterisé par la mise en œuvre de certaines approches didactiques universelles (telle que l'approche éclectique) et de principes applicables et appliqués dans l'enseignement de toute langue étrangère aujourd'hui.

Tout d'abord, nous nous pencherons sur les raisons pour lesquelles le développement de la compétence phonologique dans l'enseignement du FLE a 
été complètement et, pourtant injustement, négligé des années 1970 aux années 1990.

Puis, nous présenterons une synthèse des approches correctives élaborées par les didacticiens français les plus importants du début du $\mathrm{XXI}^{\mathrm{e}}$ siècle, qui ont mené à bien une revalorisation complète de la correction phonétique, aussi bien articulatoire que prosodique (GUIMBRETIÈRE 1994 ; CHAMPAGNEMUZAR, BOURDAGES 1998 ; LÉON 2003 ; LAURET 2007). Leur conclusion qu'au tournant du XXI ${ }^{\mathrm{e}}$ siècle la didactique des langues étrangères en général, et la didactique de la compétence phonologique en particulier, sont régies par les principes d'éclectisme qui consistent à combiner des stratégies et des approches correctives s'étant révélées efficaces et qui sont héritées des différentes méthodes didactiques (la méthode directe, la méthode audio-orale, la méthode SGAV, l'approche communicative), nous tâcherons de l'illustrer par des exemples d'exercices tirés des manuels du FLE et élaborés selon ces mêmes principes (Forum 1, Champion 1, Phonétique progressive du français avec 600 exercices, Exercices systématiques de prononciation française, Enseigner la prononciation $d u$ français). En outre, et à partir de ces mêmes exercices, nous essayerons de démontrer quels sont les avantages et d'éventuels défauts de ces stratégies correctives dans le travail avec les étudiants serbophones.

Ces exemples pourraient servir de modèles dans le développement et le perfectionnement des stratégies correctives qui combineraient plusieurs types d'exercices, qu'on pourrait « personnaliser » en fonction des besoins réels d'un groupe, d'une partie de groupe ou de quelques personnes ayant du mal à maîtriser la compétence articulatoire et intonative du français.

Mots-clefs : approche éclectique, correction articulatoire, correction prosodique, exercices de perception, exercices de production 